\title{
Biosimilar medicines: creating sustainable competition in an era of a new patent cliff in biological medicines
}

\author{
Maarten Van Baelen
}

From 3rd International PPRI Conference 2015: Pharmaceutical Pricing and Reimbursement Policies: Challenges Beyond the Financial Crisis

Vienna, Austria. 12-13 October 2015

For many years European governments have sought to ensure a high degree of competition in off-patent pharmaceutical markets in order to generate price competition and consequently benefits such as improved patient access or savings for payers after patent expiry. The pharmaceutical industry believes that access to valuable new treatments and post-exclusivity competition are essential for the sustainability of healthcare systems.

Biological medicines have become increasingly important over the last years. Twenty-seven per cent of pharmaceutical sales in Europe come from biological medicines. This market grew by $5.5 \%$ vs. a total market growth of 1.9\% in value sales between 2012 and 2013.
Many of Europe's top selling biologic molecules are facing patent expiry by 2020 [1].

Most biological medicines come at a high cost and governments have difficulty in coping with these costs in their constrained pharmaceutical budgets, especially in current times of austerity. To date, biosimilars account for less than $0.5 \%$ of the $\$ 221$ billion market of biological medicines worldwide. Biosimilars can bring huge savings for payers, and will increase the access to medicines for patients who could not otherwise afford treatment [2].

Governments must realize that biosimilar medicines are different to generic medicines and as such a unique

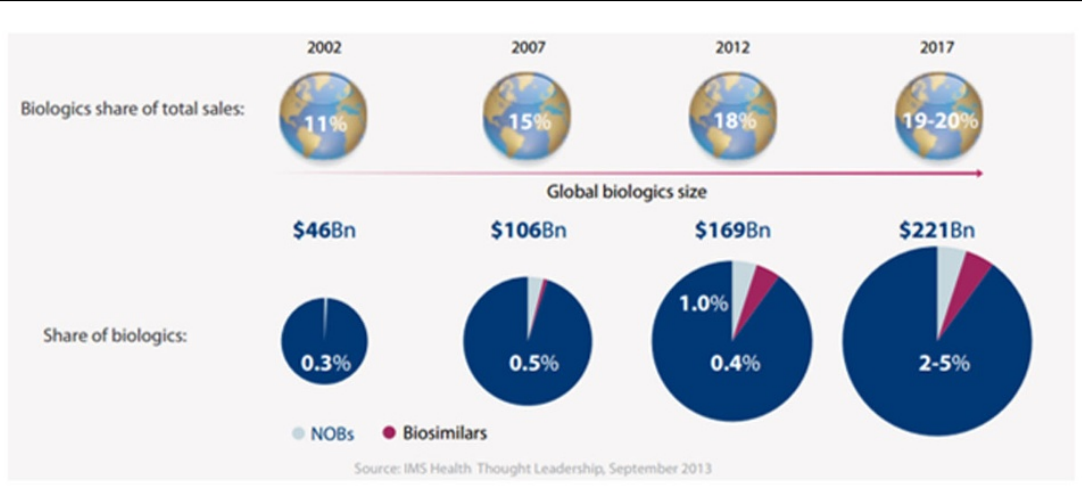

Figure 1 The biologics Market - IMS Health Thought Leadership, September 2013

Correspondence: mvanbaelen@egagenerics.com

European Generic and Biosimilar Medicines Association, Brussels, 1000, Belgium 
approach is needed. By applying the generic pricing model to biosimilar medicines, governments risk marking the biosimilar market unsustainable and patients and payers will no longer benefit.

Published: 5 October 2015

\section{References}

1. IMS Institute: Assessing biosimilar uptake and competition in European markets. 2014

2. Matti Aapro MD: Biosimilars in oncology: current and future perspectives Generics and Biosimilars Initiative Journal (GaBl Journal) 2013, 2(2):91-3.

doi:10.1186/2052-3211-8-S1-P28

Cite this article as: Van Baelen: Biosimilar medicines: creating sustainable competition in an era of a new patent cliff in biological medicines. Journal of Pharmaceutical Policy and Practice 2015 8(Suppl 1): P28.

Submit your next manuscript to BioMed Central and take full advantage of:

- Convenient online submission

- Thorough peer review

- No space constraints or color figure charges

- Immediate publication on acceptance

- Inclusion in PubMed, CAS, Scopus and Google Scholar

- Research which is freely available for redistribution

Submit your manuscript at www.biomedcentral.com/submit 